\title{
Impacts on water, soil and plants from the abandoned Miguel Vacas copper mine, Portugal
}

\author{
M.M. Abreu ${ }^{a, *}$, M.J. Matias ${ }^{b}$, M. Clara F. Magalhães ${ }^{\text {c }}$, M.J. Basto ${ }^{\text {b }}$ \\ ${ }^{a}$ Instituto Superior de Agronomia, Universidade Técnica de Lisboa (TULisbon), Tapada da Ajuda, 1349-017 Lisboa, Portugal \\ ${ }^{\mathrm{b}}$ Laboratório de Mineralogia e Petrologia, IST, Universidade Técnica de Lisboa (TULisbon), Av. Rovisco Pais, 1049-001 Lisboa, Portugal \\ ${ }^{\mathrm{c}}$ CICECO, Dep. de Química, Universidade de Aveiro, Campus de Santiago, 3810-193 Aveiro, Portugal
}

Received 1 August 2006; accepted 20 April 2007

Available online 29 June 2007

\begin{abstract}
Soil, water and plant geochemistry was studied around the Miguel Vacas copper mine (Alentejo, SE Portugal), which stopped its exploitation and processing activities in 1991. After closure waste-rock piles remained exposed to weathering. The copper ore was mainly composed of copper phosphates and carbonates. Remediation actions were insufficient to prevent the spreading of waste-rock materials to surrounding farmed fields. The latter caused contamination of soils and water. Based on overall characteristics water from wells and surface stream water mostly can be classified as of the sulphate magnesium type. The application of a chemical equilibrium model to the sampled water showed that copper, phosphate and sulphate concentrations are controlled by copper(II) secondary minerals (pseudomalachite, libethenite and malachite) and gypsum. Nevertheless, groundwater can be used for irrigation and cattle based on quality parameters.

Soils and plants (Prunus domestica L., Olea europaea L. spp. europaea and Quercus ilex L.) were collected southeast of the open pit and the exploitation substructures. The soils located in the influence of drainage water that percolated through waste material or exploitation substructures were contaminated with $\mathrm{Cu}$, and $\mathrm{Ni}$ was close to the maximum value allowed by Portuguese legislation. These soils, however, did not show elevated $\mathrm{Zn}$ and $\mathrm{Mn}$ concentrations. The trace element content in plants was within the normal range, with $Q$. ilex being able to accumulate $\mathrm{Mn}$ and to some extent also Ni. Dispersion of trace elements seemed to be limited to a distance $1500 \mathrm{~m}$ down from the waste dumps in southeastern direction.
\end{abstract}

(C) 2007 Elsevier B.V. All rights reserved.

Keywords: Phosphates, -carbonates copper mine; Soil copper contamination; Nickel; Prunus domestica; Quercus ilex

\section{Introduction}

Global cycles of trace elements have been considerably altered by human activities since the Bronze and Iron ages, which increased dramatically with the onset

\footnotetext{
* Corresponding author. Tel.: +351 213653432; fax: +351 213653432.

E-mail address: manuelaabreu@isa.utl.pt (M.M. Abreu).
}

of the industrial revolution. Among human activities, mining is responsible for contamination of water and soils in large areas of the globe.

Several elements, including $\mathrm{Cu}, \mathrm{Mn}, \mathrm{Fe}, \mathrm{Zn}, \mathrm{Ni}, \mathrm{Mo}$, $\mathrm{B}$ and $\mathrm{Cl}$ are essential micronutrients for plants. Other elements such as $\mathrm{Al}$ and $\mathrm{Ti}$ are beneficial for some plants (Srivastava and Gupta, 1996). At large concentrations, however, these elements become toxic to plants. The risk for both the environment and human health of a 
given element depends on its mobility and bioavailability. The origin of trace elements combined with the physical, chemical, mineralogical and biological characteristics of the soil influence their behaviour in soils and control their bioavailability (Kabata Pendias and Pendias, 2001; Kabata Pendias, 2004). In addition, the water quality is, in irrigated soils, another factor that must be taken into account.

In Portugal, about 90 mining areas with different dimensions and contamination levels were abandoned (Oliveira et al., 2002), and only a few were submitted to recovery programmes. Nonetheless, some of the soils and waters near small mines are used for agriculture without any assessment of environmental and human health risks. This is the case of the abandoned Miguel Vacas copper mine where a plum orchard and some olive trees are cultivated downstream from seasonal water streams originated in the waste dump or its vicinity. Although some environmental studies of copper mining areas in Portugal were already reported (Quental et al., 2002; Batista, 2003; Alvarenga et al., 2004; Freitas et al., 2004a), the uniqueness of the Miguel Vacas mine in the Portuguese and international mining context arises from the fact that copper phosphates and carbonates were the main copper ore, while copper-rich sulphides were the main copper sources in other mines. Pseudomalachite and libethenite are rare minerals although large masses of pseudomalachite were found in the Urals (Russia), and in association with libethenite, malachite and azurite in the West Bogan (McColl, 1978) and Girilambone (Chapman et al., 2005) Mines, Australia. The paragenetic sequence of copper secondary minerals is similar in the Miguel Vacas and West Bogan mines - libethenite seems to be the first mineral to be deposited followed by pseudomalachite and finally carbonates (McColl, 1978; Magalhães et al., 1988). No environmental studies have been reported for the West Bogan Mine since no ore was extracted in large quantities. Girilambone Mine was discontinuously mined for copper from 1880 to 2002 (Chapman et al., 2005). Primary ore, comprising mainly pyrite and chalcopyrite, was first exploited for copper, being mining operations centered in oxidized and supergene-enriched ores containing mainly pseudomalachite, libethenite, malachite, azurite and cuprite from 1992 to 2002 (Chapman et al., 2005).

The aim of this study was to evaluate the quality of soils and water in the vicinity of the Miguel Vacas copper mine, nine years after the abandon of the mining activity, when few remediation actions have been taken. As these soils have been submitted to tillage and irrigated with groundwater, the impact on plum and olive trees and holm oak growing in soils of the mining area was also studied.

\section{Site description}

\subsection{Regional geology and mining activity}

The Miguel Vacas copper mine is located $5 \mathrm{~km}$ southeast of Vila Viçosa (Alentejo - Portugal) (Fig. 1). This region has a temperate climate with a warm and dry summer (Csa according to Köppen classification) and an annual precipitation of about $670 \mathrm{~mm}$, occurring mainly in winter. The majority of the streams dry out during most of the year and private wells are the major source of irrigation water.

The Vila Viçosa region, well-known for its marble production, hosts some small copper deposits, which have been mined in the past but are now abandoned. The Miguel Vacas ore deposits are located in Silurian rocks (black shales, phyllites and interbedded volcanites), close to the outcrop of Portuguese Cambrian marbles (Cerveira, 1972). The ore deposit is essentially confined to an extensive vein system, approximately $25 \mathrm{~m}$ thick. Primary mineralization, located at a depth of about 80 $\mathrm{m}$, is mainly formed by sulphides (chalcopyrite and pyrite) largely confined to the quartz breccia containing silicified dolomite in some zones.

Minor lead and zinc grades have been recorded in bulk samples, but no discrete minerals of these elements have been found in any part of the deposit or its surroundings. Iron and manganese oxyhydroxides are common in the oxide zone and the exposed gossans. Other mineralization of the oxidized zone includes mainly copper phosphates and carbonates, such as pseudomalachite $\left[\mathrm{Cu}_{5}\left(\mathrm{PO}_{4}\right)_{2}\right.$ $\left.(\mathrm{OH})_{4}\right]$, libethenite $\left[\mathrm{Cu}_{2}\left(\mathrm{PO}_{4}\right)(\mathrm{OH})\right]$, azurite $\left[\mathrm{Cu}_{3}\left(\mathrm{CO}_{3}\right)_{2}\right.$ $\left.(\mathrm{OH})_{2}\right]$ and malachite $\left[\mathrm{Cu}_{2}\left(\mathrm{CO}_{3}\right)(\mathrm{OH})_{2}\right]$, which compose the main copper ore that was exploited. These secondary minerals are not confined to the vein system but are widely dispersed in the shear zone and also impregnating sections of the graphite schists and cherts in the hanging wall (Magalhães et al., 1988).

Mining activity in Miguel Vacas mine was first recorded during roman times or even earlier (Cerveira, 1972). The earlier exploitation works were done underground, while the recent works (1979-1991) were by the open pit process.

\subsection{Ore treatment}

Ore treatment in the mining area included crushing and heap leaching with aqueous sulphuric acid solutions. The resulting leachates were aqueous solutions containing mainly copper and sulphate and also phosphate ions. The copper from leachates was recovered by an electrochemical process, using metallic scrap-iron. This process 
consists in the reduction of copper(II) ions to elemental copper, while iron is oxidized to iron ions. The presence of phosphate ions in the leachates promotes and accelerates the passivation of part of the scrap-iron, by the formation of a porous thin layer of iron phosphates on the scrap-iron surface. The presence of phosphate ions in aqueous solutions increases the resistance of iron to corrosion (Gentil, 1987) and causes the incomplete copper recovery from the leachates and the discharge of some copper(II) in the surrounding water streams.
The mining activity finished in 1991, but the wasterock dumps, materials where the heap leaching occurred, remained exposed to weathering conditions.

\section{Materials and methods}

\subsection{Water, soil and plant sampling}

Ten soil profiles, about $60 \mathrm{~cm}$ deep, were chosen taking into account the drainage that percolates through

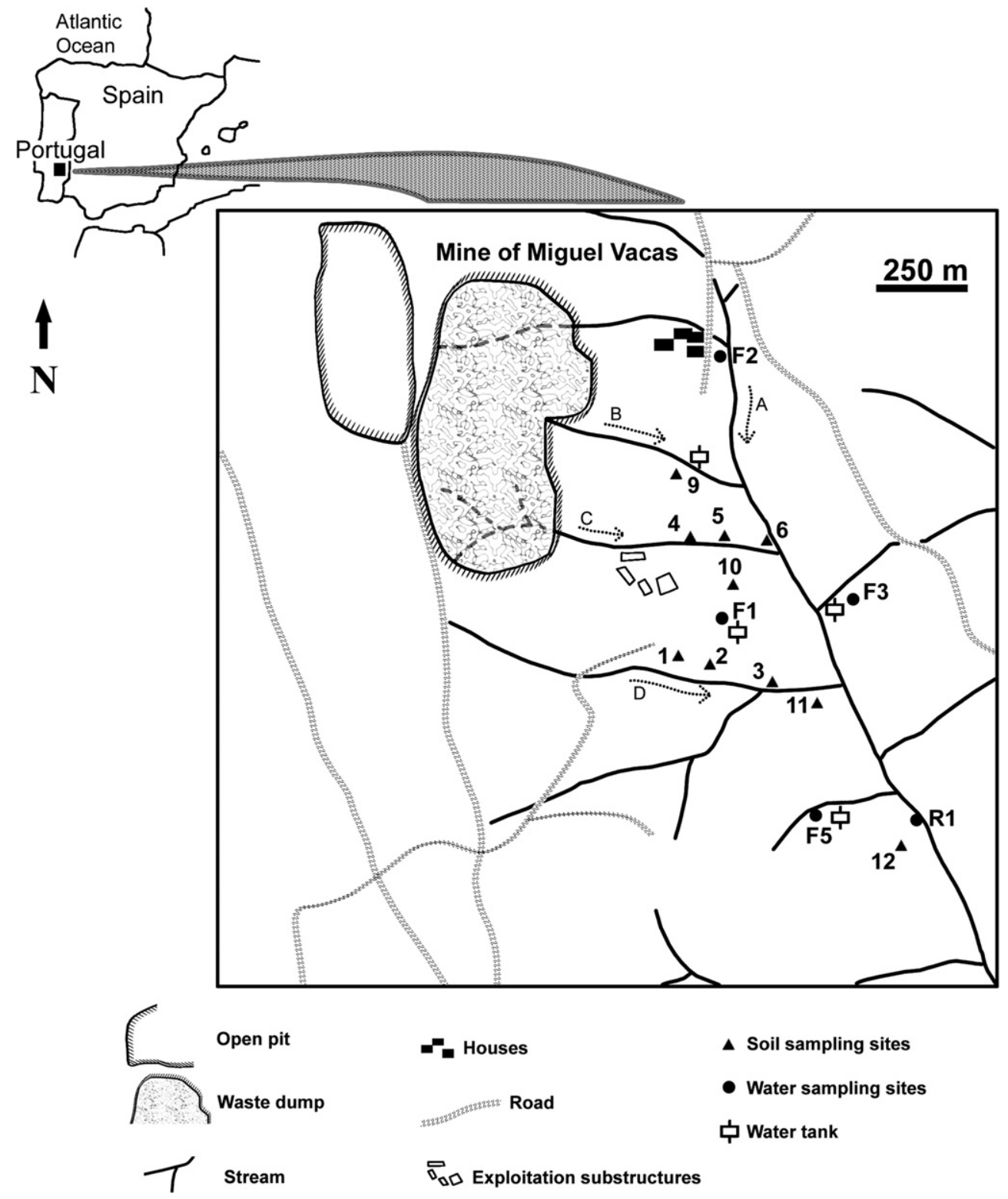

Fig. 1. Map of the Miguel Vacas region. The open pit and the waste-rock dump are shown, together with sites where soil and water samples were collected. 
the waste-rock dumps or the exploitation substructures (leachate decantation and copper recovery reservoir, and drying floor) within an approximate area of $1 \mathrm{~km}^{2}$ (Fig. 1). Twenty three soil samples were collected from soil horizons (A, B or A, B, C) in each profile.

The soils, developed on schist and phyllite colluvium and located southeast of the open pit and the exploitation substructures, are mainly cultivated with plum (Prunus domestica L.) and irrigated by drip watering system. Some of the soils are not irrigated and have olive trees (Olea europaea L. spp. europaea). Some holm oak trees (Quercus ilex L.) also grew in the sampling area.

Composite leaf samples from plum (six samples) and olive (two samples) were collected from three trees growing approximately in a $2 \mathrm{~m}$ radius around each of the 10 soil profiles. The holm oak leaves (two samples) were collected only from one tree in each of two sampling points as no more trees of this species existed.

The direction of the main water flow and sampling locations are shown in Fig. 1: stream A originates in the north extremity of the waste dump, and seasonal water streams (B, C and D) originate in the waste dump or in its vicinity. Seven water samples were collected from wells (F1, F2, F3, F5, F22, and F33) or from the permanent stream (R1). Sample F1 was collected in October 1998, samples F2 and F3 were collected in November 1999 and samples F22, F33, F5 and R1 were collected in March 2000. F22 and F33 represented a second sampling from the wells F2 and F3, respectively.
Two composite samples of the waste materials from the waste dump (Fig. 1) were also collected.

\section{Methods}

Temperature, conductivity, Eh and $\mathrm{pH}$ of water samples, collected in PVC bottles, were measured in situ. Water samples were cooled to around $4{ }^{\circ} \mathrm{C}$ and transported to the laboratory where alkalinity (ANSI/ ASTM D 1067-82 method — method B) (ASTM, 1984) was immediately measured. Around $1.2 \mathrm{~L}$ sample was filtered through a $0.45 \mathrm{~mm}$ Millipore ${ }^{\circledR}$ filter and $0.5 \mathrm{~L}$ was acidified with analytical grade concentrated nitric acid and used to measure total metal ion concentrations. Analyses for total phosphates and total sulphates by the gravimetric method were performed using the standard ASTM (1984) methods.

Physical and chemical characteristics of the soils ( $<2 \mathrm{~mm}$ fraction) were: particle size distribution by sieving and sedimentation after sodium hexametaphosphate dispersion; $\mathrm{pH}$ by electrometric method in a water suspension (1:2.5 soil/water); organic carbon by potassium dichromate oxidation; cation exchange capacity (CEC) and exchangeable cations by the ammonium acetate method at $\mathrm{pH} 7$ using a $1 \mathrm{M}$ aqueous solution (Póvoas and Barral, 1992). The clay fraction $(<2 \mu \mathrm{m})$ was separated from soil samples by water dispersion and sedimentation following Stokes law. Mineralogical analysis were undertaken in basally oriented preparations of clay by X ray Diffraction analysis

Table 1

Physical and chemical parameters of water from wells $(\mathrm{F})$ and from the stream $(\mathrm{R})$ of the Miguel Vacas mine region (total concentrations are in mg $\mathrm{L}^{-1}$ )

\begin{tabular}{|c|c|c|c|c|c|c|c|c|c|}
\hline Sample & $\mathrm{F} 1$ & $\mathrm{~F} 2$ & F3 & F22 & F33 & F5 & R1 & MRV & MAV \\
\hline Temperature $\left({ }^{\circ} \mathrm{C}\right)$ & 18.6 & 20.6 & 18.2 & 16.9 & 18.1 & 18.3 & 13.8 & - & - \\
\hline $\mathrm{pH}$ & 6.37 & 6.05 & 6.32 & 6.41 & 6.44 & 6.91 & 6.15 & $6.5-8.4$ & $4.5-9.0$ \\
\hline \multicolumn{10}{|l|}{ Conductivity } \\
\hline$(\mu \mathrm{S} / \mathrm{cm})$ & 1300 & 1327 & 739 & 1314 & 810 & 571 & 798 & 1000 & 3000 \\
\hline $\mathrm{Eh} / \mathrm{mV}$ & 18 & 284 & 266 & 230 & 253 & 245 & 252 & - & - \\
\hline$\left[\mathrm{HCO}_{3}^{-}\right]$ & 108.6 & 93.4 & 96.4 & 84.2 & 89.7 & 140.0 & 31.7 & 92 & 520 \\
\hline Phosphate & n.d. & 0.034 & 0.112 & 0.013 & 0.056 & 0.033 & 0.016 & - & - \\
\hline Sulphate & 733 & 572 & 242 & 499 & 252 & 208 & 455 & 575 & - \\
\hline Chloride & 10.0 & 31.6 & 17.0 & 38.8 & 22.5 & 13.5 & 23.9 & 70 & - \\
\hline Iron & 6.10 & 0.182 & n.d. & 0.019 & n.d. & n.d. & n.d. & 5 & - \\
\hline Copper & n.d. & 0.116 & 0.012 & 0.081 & 0.233 & 0.055 & 1.48 & 0.20 & 5 \\
\hline Zinc & 0.005 & 0.228 & n.d. & 0.385 & n.d. & n.d. & 0.053 & 2 & 10 \\
\hline Sodium & 27.0 & 61.4 & 55.7 & 63.6 & 55.8 & 15.0 & 35.3 & - & - \\
\hline Potassium & 0.06 & 1.33 & 0.75 & 1.48 & 0.80 & 1.11 & 1.1 & - & - \\
\hline Magnesium & 56 & 75.8 & 40.3 & 68.8 & 40.8 & 17.4 & 49.1 & - & - \\
\hline Calcium & 206 & 142 & 62.1 & 134 & 63.7 & 109 & 123 & - & - \\
\hline Barium & n.d. & 0.014 & n.d. & 0.011 & 0.006 & 0.027 & 0.016 & 1 & - \\
\hline
\end{tabular}

Maximum recommended values (MRV) and maximum allowed values (MAV) for irrigation water according to the Portuguese legislation (DecretoLei No. 236/98).

n.d.: not determined. 
Table 2

Total content of some elements in waste materials $\left(\mathrm{mg} \mathrm{kg}^{-1}\right.$ dry weight)

\begin{tabular}{lllllllrrr}
\hline Sample & As & $\mathrm{Ba}$ & $\mathrm{Co}$ & $\mathrm{Cu}$ & $\mathrm{Mn}$ & $\mathrm{Ni}$ & $\mathrm{P}$ & $\mathrm{Pb}$ & $\mathrm{Zn}$ \\
\hline WM1 & 950 & $<50^{\text {a }}$ & 36 & 2030 & 1620 & 117 & 980 & 33 & 97 \\
WM2 & 878 & 410 & 26 & 3480 & 1480 & 141 & 2080 & 63 & 118 \\
\hline
\end{tabular}

a Detection limit.

(XRD) using a Philips diffractometer with a graphite monochromator, and $\mathrm{Cu} \mathrm{K} \alpha$ radiation.

Soils $(<2 \mathrm{~mm}$ fraction) were analysed for total and available fraction of trace metals. Total analyses were performed in four replicates of each sample after a cold acid digestion. Each sample of $0.5 \mathrm{mg}$ was mixed with $10 \mathrm{~mL}$ of $65 \%(\mathrm{w} / \mathrm{w}) \mathrm{HNO}_{3}$ and left for $48 \mathrm{~h}$ at room temperature. The mixture was left to react at $70{ }^{\circ} \mathrm{C}$ until dry. The dry residue was mixed with $5 \mathrm{~mL}$ of $48 \%$ (w/w) $\mathrm{HF}$ and left again to dry at $70{ }^{\circ} \mathrm{C}$, when $2-3 \mathrm{~mL}$ of $1 \mathrm{M}$ $\mathrm{HNO}_{3}$ and 5-6 $\mathrm{mL} \mathrm{30 \%} \mathrm{(w/w)} \mathrm{hydrogen} \mathrm{peroxide} \mathrm{were}$ added until gas release finished (Tavares, 1995). The available fraction (two replicates) was extracted according to the first two steps of Berti et al. (1997): water soluble elements (first step) by deionised water degasified with nitrogen; and elements in exchangeable positions (second step) by $0.5 \mathrm{M}$ calcium nitrate adjusted to soil $\mathrm{pH}$.

Plant samples (leaves) were washed with tap water, rinsed with deionised water, dried at $40{ }^{\circ} \mathrm{C}$ and finely ground. Each sample of $0.5 \mathrm{mg}$ was mixed with $10 \mathrm{~mL}$ of $65 \%(\mathrm{w} / \mathrm{w}) \mathrm{HNO}_{3}$ and left for $48 \mathrm{~h}$ at room temperature. Digestion until dryness was then carried out at $70{ }^{\circ} \mathrm{C}$ and the residue dissolved with $50 \mathrm{~mL} 0.1 \mathrm{M}$ $\mathrm{HNO}_{3}$ (Tavares, 1995). Elements were measured by ICP.

Total chemical analysis of waste materials was performed by ICP and INAA after four acid ( $\mathrm{HF}, \mathrm{HClO}_{4}$, $\mathrm{HNO}_{3}$ and $\mathrm{HCl}$ ) digestions on Actlabs Laboratories (Canada).

Univariate and bivariate (Pearson and Spearman correlation coefficients) statistics were used for data analysis.

Table 3

Physical and chemical characteristics of the soils in the Miguel Vacas mining area

\begin{tabular}{|c|c|c|c|c|c|c|c|c|c|}
\hline \multirow{3}{*}{$\begin{array}{l}\text { Soil } \\
\text { profile/horizon }\end{array}$} & \multirow{3}{*}{$\begin{array}{l}\mathrm{pH} \\
\left(\mathrm{H}_{2} \mathrm{O}\right)\end{array}$} & \multirow{2}{*}{$\begin{array}{l}\text { Organic } \\
\text { carbon }\end{array}$} & \multirow{2}{*}{$\begin{array}{l}\text { Clay } \\
(<2 \mu \mathrm{m})\end{array}$} & \multirow{2}{*}{$\begin{array}{l}\text { Silt } \\
(2-20 \mu \mathrm{m})\end{array}$} & \multirow[t]{2}{*}{ CEC } & \multicolumn{4}{|c|}{ Exchangeable cations } \\
\hline & & & & & & $\overline{\mathrm{Ca}}$ & $\mathrm{Mg}$ & $\mathrm{K}$ & $\mathrm{Na}$ \\
\hline & & \multicolumn{3}{|l|}{$\mathrm{g} \mathrm{kg}^{-1}$} & \multicolumn{5}{|l|}{$\mathrm{cmol}_{\mathrm{c}} \mathrm{kg}^{-1}$} \\
\hline \multicolumn{10}{|c|}{ Soil group A ( $p H \leq 5$ in B horizon) } \\
\hline $\mathrm{p} 1 \mathrm{~A}$ & 5.73 & 15.92 & 179 & 455 & 8.55 & 3.22 & 0.64 & 0.33 & 0.06 \\
\hline p1B & 4.95 & 2.88 & 398 & 363 & 8.84 & 1.49 & 0.69 & 0.28 & 0.03 \\
\hline $\mathrm{p} 3 \mathrm{~A}$ & 5.83 & 9.35 & 192 & 428 & 11.27 & 7.09 & 1.12 & 0.16 & 0.06 \\
\hline $\mathrm{p} 3 \mathrm{~B}$ & 4.68 & 6.54 & 207 & 392 & 10.63 & 3.84 & 0.87 & 0.79 & 0.07 \\
\hline $\mathrm{p} 3 \mathrm{C}$ & 4.76 & 3.65 & 212 & 326 & 9.53 & 4.09 & 1.09 & 0.26 & 0.05 \\
\hline $\mathrm{p} 4 \mathrm{~A}$ & 7.27 & 15.54 & 184 & 427 & 13.83 & 15.85 & 0.89 & 0.05 & 0.06 \\
\hline $\mathrm{p} 4 \mathrm{~B}$ & 4.50 & 5.62 & 176 & 443 & 10.92 & 1.95 & 0.16 & 0.97 & 0.05 \\
\hline $\mathrm{p} 5 \mathrm{~A}$ & 7.31 & 9.11 & 190 & 374 & 12.37 & 11.46 & 1.38 & 0.12 & 0.07 \\
\hline $\mathrm{p} 5 \mathrm{~B}$ & 4.75 & 8.62 & 222 & 370 & 12.76 & 6.66 & 1.30 & 0.83 & 0.08 \\
\hline p6A & 6.59 & 14.96 & 162 & 391 & 13.27 & 16.55 & 0.99 & 0.13 & 0.04 \\
\hline p6B & 5.17 & 14.09 & 178 & 423 & 13.36 & 5.73 & 1.03 & 1.51 & 0.03 \\
\hline p9A & 5.08 & 6.9 & 181 & 370 & 9.19 & 2.57 & 0.74 & 0.17 & 0.02 \\
\hline p9B & 4.73 & 2.9 & 190 & 418 & 6.76 & 1.81 & 0.68 & 0.16 & 0.02 \\
\hline p9C & 4.60 & 2.3 & 187 & 436 & 6.09 & 1.59 & 0.71 & 0.83 & 0.02 \\
\hline \multicolumn{10}{|c|}{ Soil group B ( $p H>6$ in B horizon) } \\
\hline $\mathrm{p} 2 \mathrm{~A}$ & 7.60 & 5.01 & 258 & 461 & 10.72 & 18.61 & 1.51 & 0.14 & 0.22 \\
\hline $\mathrm{p} 2 \mathrm{~B}$ & 7.46 & 2.20 & 328 & 386 & 10.24 & 9.02 & 0.95 & 0.09 & 0.09 \\
\hline $\mathrm{p} 2 \mathrm{C}$ & 7.13 & 1.23 & 307 & 410 & 8.26 & 5.71 & 1.02 & 0.20 & 0.06 \\
\hline p10A & 6.40 & 16.9 & 205 & 354 & 36.87 & 13.19 & 3.78 & 0.13 & 0.08 \\
\hline $\mathrm{p} 10 \mathrm{~B}$ & 7.07 & 2.3 & 251 & 276 & 12.41 & 15.55 & 9.97 & 0.06 & 0.12 \\
\hline p11A & 7.15 & 10.5 & 190 & 390 & 11.38 & 10.82 & 2.41 & 0.05 & 0.13 \\
\hline p11B & 6.33 & 9.4 & 251 & 447 & 11.82 & 11.01 & 2.68 & 0.09 & 0.15 \\
\hline $\mathrm{p} 12 \mathrm{~A}$ & 7.12 & 8.5 & 358 & 383 & 11.84 & 9.49 & 1.74 & 0.28 & 0.07 \\
\hline p12B & 6.68 & 3.7 & 373 & 419 & 11.34 & 7.05 & 1.94 & 0.41 & 0.10 \\
\hline
\end{tabular}

CEC: cation exchange capacity. 


\section{Results and discussion}

\subsection{Interaction water-solid phases}

Water from wells can be classified as sulphate magnesium type (Table 1), as expected from the occurrence of metasedimentary rocks (e.g. schists). Calcium was also present as a major cation and the sample F1 was a calcium sulphate water (Magalhães et al., 1999).

Equilibrium activities and species distribution for all the aqueous samples were calculated using the computer program PHREEQC (Parkhurst, 1995) and the input data is shown in Table 1 . The solubility constants for cornetite $\left[\mathrm{Cu}_{3}\left(\mathrm{PO}_{4}\right)(\mathrm{OH})_{3}\right]$, libethenite $\left[\mathrm{Cu}_{2}\left(\mathrm{PO}_{4}\right)(\mathrm{OH})\right]$, pseudomalachite $\left[\mathrm{Cu}_{5}\left(\mathrm{PO}_{4}\right)_{2}(\mathrm{OH})_{4}\right]$ and tarbuttite $\left[\mathrm{Zn}_{2}\left(\mathrm{PO}_{4}\right)\right.$ $(\mathrm{OH})]$ were taken from Magalhães et al. $(1986,1988)$ and

Table 4

Range (minimum and maximum) of copper, manganese, nickel, zinc and phosphorous contents ( $\mathrm{mg} \mathrm{kg}^{-1}$ dry weight) in soils (total and available fraction) and plants

\begin{tabular}{|c|c|c|c|c|c|}
\hline & $\mathrm{Cu}$ & $\mathrm{Mn}$ & $\mathrm{Ni}$ & $\mathrm{Zn}$ & $\mathrm{P}$ \\
\hline \multicolumn{6}{|c|}{ Soil group $A$ ( $p H \leq 5$ in $B$ horizon $)$} \\
\hline \multicolumn{6}{|l|}{ A horizon } \\
\hline Total & $\begin{array}{l}410.7- \\
2231.4\end{array}$ & $\begin{array}{l}1446.2- \\
4152.7\end{array}$ & $\begin{array}{l}37.3- \\
105.9\end{array}$ & $\begin{array}{l}52.9- \\
211.4\end{array}$ & $\begin{array}{l}533.8- \\
1043.7\end{array}$ \\
\hline Available & $\begin{array}{l}9.8- \\
489.8\end{array}$ & $\begin{array}{l}33.4- \\
176.1\end{array}$ & nd & $\begin{array}{l}<\mathrm{dl}- \\
7.0\end{array}$ & nd \\
\hline \multicolumn{6}{|l|}{ B horizon } \\
\hline Total & $\begin{array}{l}79.7- \\
1386.5\end{array}$ & $\begin{array}{l}914.8- \\
5258.9\end{array}$ & $\begin{array}{l}49.6- \\
143.4\end{array}$ & $\begin{array}{l}54.5- \\
184.3\end{array}$ & $\begin{array}{l}484.7- \\
936.4\end{array}$ \\
\hline Available & $\begin{array}{l}2.4- \\
325.7\end{array}$ & $\begin{array}{l}105.4- \\
353.5\end{array}$ & nd & $\begin{array}{l}4.2- \\
10.2\end{array}$ & nd \\
\hline \multicolumn{6}{|l|}{ Plant } \\
\hline Plum tree* & $\begin{array}{l}4.2- \\
18.3\end{array}$ & $\begin{array}{l}92.0- \\
1053.7\end{array}$ & $\begin{array}{l}1.3- \\
14.3\end{array}$ & $\begin{array}{l}5.4- \\
51.0\end{array}$ & $\begin{array}{l}2274.0- \\
5312.1\end{array}$ \\
\hline Olive tree* & 8.3 & 82.2 & 7.8 & 20.1 & 1789.1 \\
\hline Holm oak* & 9.9 & 1159.4 & 16.3 & 36.3 & 927.0 \\
\hline \multicolumn{6}{|c|}{ Soil group $B$ ( $p H>6$ in $B$ horizon $)$} \\
\hline \multicolumn{6}{|c|}{ A horizon } \\
\hline Total & $\begin{array}{l}66.9- \\
534.6\end{array}$ & $\begin{array}{l}1688.9- \\
2284.1\end{array}$ & $\begin{array}{l}47.5- \\
67.2\end{array}$ & $\begin{array}{l}52.7- \\
72.6\end{array}$ & $\begin{array}{l}581.6- \\
983.9\end{array}$ \\
\hline Available & $2.2-6.4$ & $\begin{array}{l}7.8- \\
44.8\end{array}$ & nd & $\begin{array}{l}<\mathrm{dl}- \\
0.3\end{array}$ & nd \\
\hline \multicolumn{6}{|l|}{ B horizon } \\
\hline Total & $\begin{array}{l}43.5- \\
163.6\end{array}$ & $\begin{array}{l}1686.4- \\
2154.0\end{array}$ & $\begin{array}{l}54.0- \\
72.1\end{array}$ & $\begin{array}{l}37.0- \\
116.5\end{array}$ & $\begin{array}{l}468.1- \\
1000.7\end{array}$ \\
\hline Available & $1.9-2.8$ & $\begin{array}{l}8.2- \\
37.8\end{array}$ & nd & $\begin{array}{l}<\mathrm{dl}- \\
0.6\end{array}$ & nd \\
\hline \multicolumn{6}{|l|}{ Plant } \\
\hline Plum tree & $\begin{array}{l}4.6- \\
21.4\end{array}$ & $\begin{array}{l}57.2- \\
115.2\end{array}$ & $\begin{array}{l}2.0- \\
2.3\end{array}$ & $\begin{array}{l}6.6- \\
56.9\end{array}$ & $\begin{array}{l}2274.0- \\
6683.1\end{array}$ \\
\hline Olive tree & 10.6 & 42.2 & 3.6 & 26.6 & 2178.5 \\
\hline Holm oak & 8.8 & 4000.2 & 9.4 & 21.0 & 1179.8 \\
\hline
\end{tabular}

ld: detection limit; n.d.: not determined; * Plum tree - Prunus domestica L., olive tree - O. europaea L. spp. europaea, holm oak Quercus ilex L. hopeite $\left[\mathrm{Zn}_{3}\left(\mathrm{PO}_{4}\right)_{2} \cdot 4 \mathrm{H}_{2} \mathrm{O}\right]$ from Nriagu (1973) and Perez and Nancollas (1984) were added to the constants as presented in the MINTEC database. The saturation index, calculated using the above program for all the solid phases considered in the database, gives information on the possibility of saturation with respect to some solid phases and also on the solid phase that can control some chemical species concentration, in the waters. According to these parameters, for the samples F2, F22, F5 and R1 the concentration of calcium seems to be controlled by the solubility of calcium sulphates (anhydrite or gypsum). The concentration of barium, when measurable, is controlled by the solubility of barite, the concentration of sulphate is controlled by the solubility of the barium and calcium sulphate-containing minerals, and the concentration of phosphate, in sample F5, seems to be controlled by the solubility of hydroxyapatite $\left[\mathrm{Ca}_{5}\left(\mathrm{PO}_{4}\right)\right.$ $(\mathrm{OH})]$.

Iron(II), zinc(II), and copper(II) sulphates are very soluble in water. Zinc levels in all waters were too low to reach any equilibrium with solid phases (carbonates, phosphates and sulphates) considered in the computing programme. Copper content in the samples F3, F33, F5 and $\mathrm{R} 1$ shows that these waters can be in equilibrium with the copper phosphate, pseudomalachite. These data are in agreement with the observed mineralogy of the region where no zinc minerals have been found, pseudomalachite is often crystallised over libethenite, and iron and manganese oxides and hydroxides are widely spread all over the region (Magalhães et al., 1988).

Data in Table 1 also show that the water samples had large values for some parameters such as conductivity, copper, and iron, although smaller than the maximum allowed value (MAV) for irrigation water, according to the Portuguese legislation (Decreto Lei $n^{\circ}$ 236/98).

\subsection{Waste materials}

Since mineralization took place mainly in the oxidized zone, $\mathrm{Cu}, \mathrm{As}, \mathrm{Mn}$ and $\mathrm{P}$ occurred in large concentrations in waste materials (Table 2). Despite extraction of copper, this element was still present in high levels as its recovery was not efficient due to iron passivation. The other heavy metals ( $\mathrm{Ni}, \mathrm{Zn}, \mathrm{Co}$ and $\mathrm{Pb}$ ) were within the normal range in the region for black shales, phyllites and interbedded volcanites.

\subsection{Soils and plants}

The soils were distributed into two groups based on the $\mathrm{pH}$ of the B horizon: $\mathrm{pH} \leq 5$ (Group $\mathrm{A}$ ) and $\mathrm{pH}>6$ (Group B) (Table 3). According to the FAO classification (1988), 


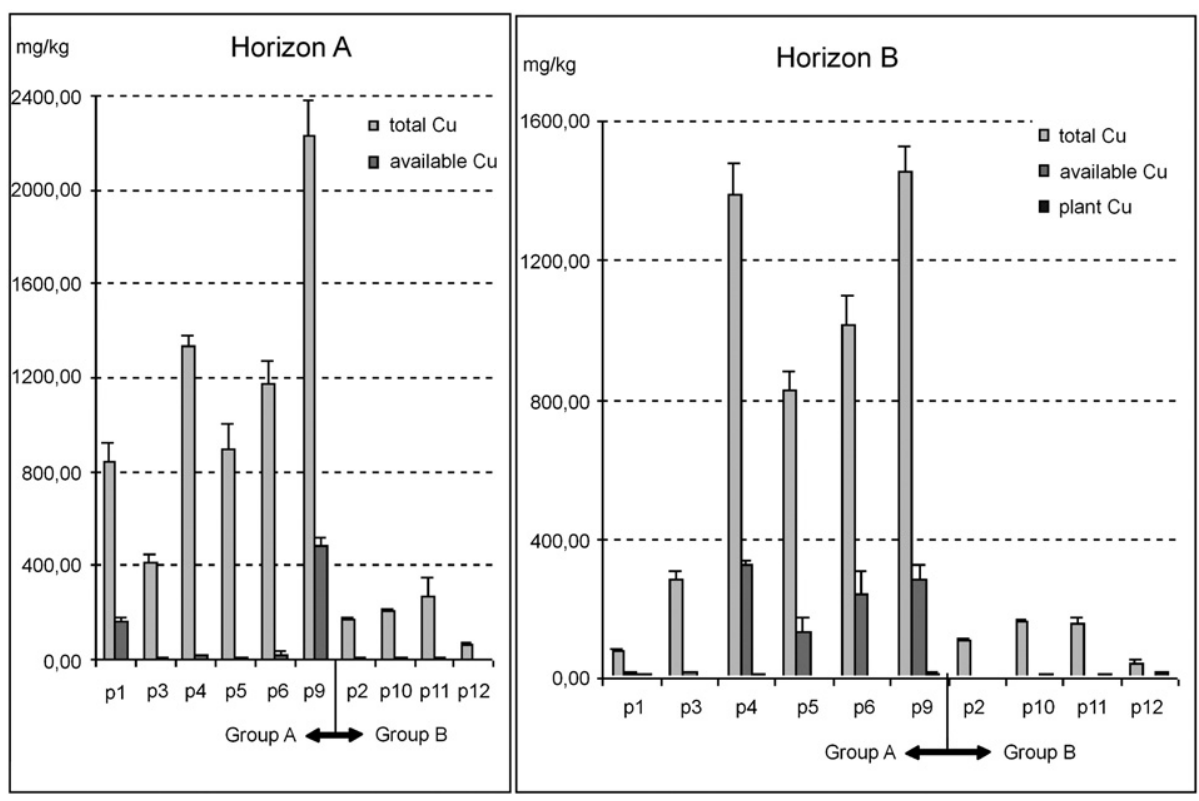

Fig. 2. Copper content in plants and total and available fraction in $\mathrm{A}$ and $\mathrm{B}$ horizons from soils of Groups $\mathrm{A}(\mathrm{pH} \leq 5$ in $\mathrm{B}$ horizon) and $\mathrm{B}$ (pH $>6$ in $\mathrm{B}$ horizon) ( $n=4$ for plants and total soil content; $n=2$ for available fraction; error bars represent standard deviation of the mean).

group A includes one Haplic Acrisol (Ach) — profile p1, four Eutric Cambisols (CMe) - profiles p3, p5, p6, p9 and one Dystric Cambisol (CMd) - profile p4. Profiles p2 and p11 classified as Haplic Luvisols (LVh) belong to Group B, as well as profile p10 (Chromic Luvisol LVx) and profile p12 (Eutric Regosol - RGe). Soils under the influence of water from the seasonal stream $\mathrm{C}$ (Fig. 1) which drains the waste dump materials (profiles $\mathrm{p} 4, \mathrm{p} 5$, and $\mathrm{p} 6$ ), had a marked $\mathrm{pH}$ difference between A and $\mathrm{B}$ horizons, which ranged, respectively, from neutral values $(\mathrm{pH} 6.6-7.3)$ to acid values $(\mathrm{pH} 4.5-5.2)$. As farmers did not lime these soils, this may be due to deep water percolation affecting preferentially the B horizon. These differences may also be a consequence of rock materials spread on some of the more affected areas by leachates from ore treatment in an attempt to minimize soil surface contamination.

Soil texture was mainly silty loam, with the silt fraction $(2-20 \mu \mathrm{m})$ being in general greater than the clay fraction. Organic matter was low or even very low (Table 3), in agreement with the climatic conditions of the region. Kaolinite, illite and vermiculite were the main clay minerals present in all samples. However, interstratified minerals, such as illite-vermiculite and illite-vermiculite-smectite, were also present in minor quantities. Soil mineralogy, texture and organic carbon are responsible for the average to low soil cation exchange capacity (CEC). Calcium was the exchangeable cation dominant in all soil profiles.
Soils of both groups, with the exception of profile p12, can be considered contaminated with copper (Table 4) according to the Portuguese legislation (Portaria 176/96, 50 and $100 \mathrm{mg} \mathrm{kg}^{-1}$, respectively, for soil $\mathrm{pH} \leq 5$ and $5<\mathrm{pH} \leq 7$ ). Soils p4, p5, p6 and p9, included in Group A and located along the direct drainage from the waste

Table 5

Copper, manganese and zinc soil available fraction: water soluble and exchangeable (calcium nitrate)

\begin{tabular}{clll}
\hline \multicolumn{1}{c}{$\mathrm{Cu}$} & $\mathrm{Mn}$ & $\mathrm{Zn}$ \\
\hline $\begin{array}{c}\text { Soil group } A(p H \leq 5 \\
\text { in B horizon) }\end{array}$ & & \\
A horizon & & & \\
Water soluble & $1.3-2.9$ & $0.8-2.6$ & $0-1.2$ \\
& $(1.8)$ & $(1.3)$ & $(0.6)$ \\
Exchangeable & $0.13-20.4$ & $0.2-8.2(2.9)$ & $0-10.5(2.7)$ \\
& $(6.2)$ & & \\
B horizon & & & $0-1.8$ \\
Water soluble & $1.6-6.8$ & $0.6-1.8$ & $(1.1)$ \\
& $(3.0)$ & $(1.3)$ & $4.2-11.5$ \\
Exchangeable & $6.4-22.7$ & $1.7-11.0$ & $(8.4)$ \\
& $(15.8)$ & $(7.0)$ & \\
Soil group B (pH>6 in B horizon) & & $0-0.4$ \\
A horizon & & & $(0.2)$ \\
Water soluble & $0.9-3.2$ & $0.2-1.7$ & 0 \\
Exchangeable & $(1.8)$ & $(1.1)$ & \\
B horizon & $(0.3)$ & $0.2-1.0$ & $(0.6)$ \\
Water soluble & $0.9-2.4(1.6)$ & $0.1-1.1(0.6)$ & $0-0.5(0.3)$ \\
Exchangeable & $0-2.0(0.7)$ & $0.4-1.1(0.7)$ & 0
\end{tabular}

Minimum, maximum (and mean) in \% of total element concentration. 
dump, had the largest $\mathrm{Cu}$ content (Fig. 2). Total $\mathrm{Cu}$ was present mainly in the A horizons (Fig. 2), reflecting $\mathrm{Cu}$ affinity for organic matter (Table 3 ) and the relative high levels of illite, vermiculite or interstratified 2:1 minerals in B horizons, whereas in A horizons, kaolinite was generally the dominant clay mineral present. However, no significant correlations were obtained between total copper and organic carbon or CEC. The copper available fraction (water soluble plus exchangeable) was greatest in soils of Group A (Table 5), but, while in soils of Group A the exchangeable fraction was greater than the water soluble fraction, the reverse was true in soils of Group B. The copper available fraction was positively correlated to total $\mathrm{Cu}\left(r^{2}=0.96\right.$ and $r^{2}=0.62$, respectively, for the $\mathrm{B}$ and A horizons, $n=6$ ) and negatively correlated to soil $\mathrm{pH}$ $\left(r^{2}=0.69, n=6\right)$ in the B horizon.

Total Mn was, in general, in the normal range for soils (200-3000 mg kg-1, Srivastava and Gupta, 1996) with the exception of soils p3 and p4 that had between 3907 and $5259 \mathrm{mg} \mathrm{kg}^{-1}$. The percentage of manganese in the available fraction was relatively small $(<1.6 \%$ for group B soils, Table 5), when compared with the total content, and followed the $\mathrm{Cu}$ behaviour for water soluble and exchangeable fractions. In fact, the concentration of the $\mathrm{Mn}$ available fraction was above the critical concentration ranges for Mn deficiency in crops (Srivastava and Gupta, 1996).

Total zinc levels were smaller than the maximum allowed value (MAV) according to the Portuguese legislation (150 and $300 \mathrm{mg} \mathrm{kg}^{-1}$, respectively, for soil $\mathrm{pH} \leq 5$ and $5<\mathrm{pH} \leq 7)$ and the concentration of the available fraction was, in most of samples of Group B, under the detection limit. On the other hand, this fraction (Table 5) in Group A of soils was above the range for the critical levels generally accepted for $\mathrm{Zn}$ deficiency (Srivastava and Gupta, 1996). However, for both extractant solutions $\mathrm{Zn}$ was lower than the detection limit in the A horizon of soil p6.

In spite of the presence of copper phosphates in the mineralization, the soil $\mathrm{P}$ content was in the range referred for soils in general (Mengel and Kirkby, 2001). This was probably a consequence of the ore treatment with formation of low soluble iron phosphates on scrap-iron. In addition, phosphate solid phases in waste-rock piles had low solubility (Magalhães et al., 1988) and consequently $\mathrm{P}$ was not spread in soils by water (Table 1).

Total nickel content was very close to the MAV (Portaria 176/96) according to soil $\mathrm{pH}$ (30 and $75 \mathrm{mg} \mathrm{kg}^{-1}$, respectively, for $\mathrm{pH} \leq 5$ and $5<\mathrm{pH} \leq 7$ ), and in some soil profiles of Group A was even above these values. In addition, soils p3 and p4 had, in A and B horizons respectively, $\mathrm{Ni}$ concentrations greater than the level at which toxicity for plants occurs $\left(100 \mathrm{mg} \mathrm{kg}^{-1}\right.$, Mengel and Kirkby, 2001). In fact, plum leaves in soil p 3 contained $14.3 \mathrm{mg} \mathrm{Ni} \mathrm{kg}{ }^{-1}$ which is considered toxic for crops (Kabata Pendias and Pendias, 2001), but the ratio Ni/ $\mathrm{Fe}<1$, in sampled plants, excluded the potential toxicity. All the plants collected contained $\mathrm{Ni}$ above the normal value $\left(<1 \mathrm{mg} \mathrm{kg}^{-1}\right.$ ) for most crops (Srivastava and Gupta, 1996). However, leaves of holm oak (Table 4) from soil $\mathrm{p} 1$ (37.3 and $50.8 \mathrm{mg} \mathrm{Ni} \mathrm{kg}^{-1}$, respectively, for A and B horizons) had a Ni concentration $\left(19.3 \mathrm{mg} \mathrm{kg}^{-1}\right.$ dry weight) similar to that of trees grown in a serpentine region (1352 and $20.6 \mathrm{mg} \mathrm{kg}^{-1}$, respectively, for soil and plant) as reported by Freitas et al. (2004b). In addition, holm oak growing in soils of a mining area studied by Freitas et al. (2004a), with similar Ni levels $\left(42.7 \mathrm{mg} \mathrm{kg}^{-1}\right)$ to those of the Miguel Vacas soils, had a smaller Ni content (3-3.4 mg $\mathrm{kg}^{-1}$ ) than those of samples in this study.

Copper content (Table 3; Fig. 2) was in the normal range for cultivated plants (Srivastava and Gupta, 1996; Kabata Pendias and Pendias, 2001) and even for wild plants growing in soils of copper mine areas (Batista, 2003; Alvarenga et al., 2003; Freitas et al., 2004a). However the $\mathrm{Cu}$ content in $Q$. ilex leaves was approximately twice the value reported by Freitas et al. (2004a,b) for the same species grown in soils with similar $\mathrm{Cu}$ content.

Zinc level in plum leaves growing on soils p2, p5 and p6 was relatively small $\left(<10 \mathrm{mg} \mathrm{kg}^{-1}\right)$, which seems to be related to the low available fraction of the element. However, no significant correlation was found between total or available $\mathrm{Zn}$ and plant content. The zinc content was in general below the levels found in plants growing in other Portuguese mining areas (Batista, 2003; Alvarenga et al., 2004; Freitas et al., 2004a). Plum and olive trees had Mn concentrations within the range considered sufficient or normal for plants (Kabata Pendias and Pendias, 2001). However, except for olive trees, the plum and holm oak leaves had a ratio $\mathrm{Fe} / \mathrm{Mn}<1.5$, which may indicate iron chlorosis due to $\mathrm{Mn}-\mathrm{Fe}$ antagonism (Srivastava and Gupta, 1996). In addition, Q. ilex leaves with 1159.4 and $4000.2 \mathrm{mg} \mathrm{Mn} \mathrm{kg}^{-1}$, respectively, in soil p1 and soil p11 seemed to accumulate $\mathrm{Mn}$, in contrast to the results obtained by Freitas et al. (2004b) in soils with similar Mn content.

For all the elements analysed no significant correlations were obtained between total and available soil fraction content and plant concentrations.

\section{Conclusions}

Groundwater can be used for irrigation and cattle based on the risk of soil alkalization and salinization and trace metals content. Deep acid mine drainage can be one of the 
sulphate sources as well as the explanation for the calcium concentrations found in the water, that shows a greater mobilization of calcium than that existing in typical limestone regions. Copper phosphates (libethenite and pseudomalachite) are the most abundant copper minerals in the waste-rock piles. The low solubility of these minerals, under normal weathering conditions, means that copper contamination of the surrounding environment by rain water probably does not take place.

The area occupied by waste materials, the exploitation substructures and the open pit is, even today, the most contaminated site where very few plants grow. In fact, in the zone located $300 \mathrm{~m}$ from the waste dump in the southeast direction, between seasonal stream B and the exploitation structures, acid weathered rock outcrops are present together with waste materials. Downwards from this area, on coluvial materials, soils developed and are now cultivated. The soils were divided into two groups according to the $\mathrm{B}$ horizon $\mathrm{pH}(\mathrm{pH} \leq 5$ or $\mathrm{pH}>6)$. The soils located in the influence of drainage water that percolates through the waste-rock dumps or in the exploitation substructures (leachate decantation and copper recovery reservoir, and drying floor) were contaminated with copper. Eight soil profiles had total $\mathrm{Cu}$ contents between 80 and $2231 \mathrm{mg} \mathrm{kg}^{-1}$. Soil p9 was the most contaminated and plum trees growing nearby presented poor growth or even died and were replaced. One of the non-contaminated soils (profile p2) located close to the seasonal water stream $\mathrm{D}$ has been protected from contamination by an old structure not associated with mining. The other noncontaminated soil (profile p12) is located about $1500 \mathrm{~m}$ from the waste dump. Concerning the other metals analysed, only Ni presented levels close to the MAV. Soil contamination seems to be confined to the area between the waste dumps, in the southeast direction, and soil profile $\mathrm{p} 12$, as $\mathrm{Cu}$ concentration decreased with distance from source. Trace elements content in all trees, except in holm oak, was in the normal range for plants. This species was able to accumulate $\mathrm{Mn}$ and to some extent also Ni.

This study indicates that a recovery programme should be implemented in the area in spite of a small content of potential hazardous elements in plants and no evidence of water contamination. Landscape recovery on the open pit, waste dump and the area up to $300 \mathrm{~m}$ from the waste materials is needed. The contaminated soils should be amended with organic matter and, if acid, with liming materials.

\section{Acknowledgements}

The authors wish to thank the owners of the farms for permission to collect water and soil samples. Thanks also to Sónia Semedo for the determination of total metal concentrations in soils and plants, Eugénio Soares for all the ICP analysis, Nuno Leitão and Susana Silva for field work assistance and Nuno Sousa for PHREEQC calculations. Thanks to P. A. Williams for the information on copper mining from supergene secondary copper phosphates. We also acknowledge the suggestions made by the referees, that have considerably improved the paper. This study was financially supported by the Portuguese Foundation for Science and Technology (project 2/2.1/ CTA/235/94).

\section{References}

Alvarenga, P.M., Araújo, M.F., Silva, J.A.L., 2004. Elemental uptake and root-leaves transfer in Cistus ladanifer L. growing in a contaminated pyrite mining area (Aljustrel — Portugal). Water, Air and Soil Pollution 162, 81-96.

ASTM-American Society for Testing of Materials, 1984. Annual Book of ASTM Standards, vol. 11.01

Batista, M.J., 2003. Comportamento de elementos químicos no sistema rocha-solo-sedimento-planta na área mineira de Neves Corvo: Implicações ambientais. Unpublished PhD Thesis. Universidade de Aveiro.

Berti, W.R., Cunningham, S.D., Jacobs, L.W., 1997. Sequential chemical extraction of trace elements: development and use in remediating contaminated soils. In: Prost, R. (Ed.), Contaminated Soils. INRA, Paris, pp. 121-131.

Cerveira, A.M., 1972. Relatório interno ${ }^{\circ} 1$ da EMIL - Minas de Cobre de Vila Viçosa ou de Miguel Vacas.

Chapman, J.R., Sharpe, J.L., Williams, P.A., 2005. The copper deposits at Girilambone, New South Wales. Australian Journal of Mineralogy 11 (2), 91-99.

Decreto Lei ${ }^{\circ}$ 236/98. Diário da República, I Série-A n 176/98 de 1 de Agosto de 1998: 3676-3721.

FAO, 1988. FAO/UNESCO Soil Map of the World, Revised Legend. World Soil Resources. Report, vol. 60. Rome.

Freitas, H., Prasad, M.N.V., Pratas, J., 2004a. Plant community tolerant to trace elements growing on the degraded soils of São Domingos mine in the south east of Portugal: environmental implications. Environment International 30, 65-72.

Freitas, H., Prasad, M.N.V., Pratas, J., 2004b. Analysis of serpentinophytes from north-east of Portugal for trace metal accumulation relevance to the management of mine environment. Chemosphere $54,1625-1642$.

Gentil, V., 1987. Corrosão. Editora Guanabara, Rio de Janeiro, Brasil.

Kabata Pendias, A., 2004. Soil-plant transfer of trace elements - an environmental issue. Geoderma 122, 143-149.

Kabata Pendias, A., Pendias, H., 2001. Trace elements in soils and plants, 3rd ed. CRC Press, Boca Raton, FL.

Magalhães, M.C.F., Pedrosa de Jesus, J.D., Williams, P.A., 1986. Stability constants and formation of $\mathrm{Cu}$ (II) and $\mathrm{Zn}$ (II) phosphate minerals in the oxidized zone of base metal orebodies. Mineralogical Magazine 50, 33-39.

Magalhães, M.C.F., Pedrosa de Jesus, J.D., Williams, P.A., 1988. Copper(II) phosphate minerals from the Miguel Vacas mine, Alentejo, Portugal. Journal of the Russell Society 2 (1), 13-18.

Magalhães, M.C.F., Matias, M.J., Graça, R.C., Abreu, M.M., 1999. Interpretação de fenómenos geoquímicos no ambiente envolvente da 
Mina de cobre de Miguel Vacas (Alentejo) com base em modelos de equilíbrio químico. Actas II Congresso Ibérico de Geoquímica /XI Semana de Geoquímica, IST, Lisboa, Portugal, pp. 449-451.

McColl, D.H., 1978. Pseudomalachite from near Tottenham. N.S.W. Australian Mineralogist 16, 77-79.

Mengel, K., Kirkby, E.A., 2001. Principles of Plant Nutrition, 5th ed. Kluwer Academic Publishers, NL.

Nriagu, J.O., 1973. Solubility equilibrium constant of $\alpha$-hopeite. Geochimica Cosmochimica Acta 33, 2357-2361.

Oliveira, J.M.S., Farinha, J., Matos, J.X., Ávila, P., Rosa, C., Canto Machado, M.J., Daniela, F.S., Martins, L., Machado Leite, M.R., 2002. Diagnóstico ambiental das principais áreas mineiras degradadas do País. Boletim de Minas, Lisboa 39 (2), 67-85.

Parkhurst, D.L., 1995. User's Guide to PHREEQC — a computer program for speciation, reaction-path, advective-transport, and inverse geochemical calculations. Water-Resources Investigations Report, vol. 95-4227. U.S. Geological Survey, Hydrologic Analysis Software Support Program.
Perez, L., Nancollas, G.H., 1984. The kinetics of crystallization of hopeite. Journal of Crystal Growth 66, 412-418.

Portaria 176/96. 3 de Outubro de 1996 (IISérie). Transposal of Directive n 86/278 CEE. Ministério da Agricultura, do Desenvolvimento e das Pescas e do Ambiente.

Póvoas, I., Barral, M.F., 1992. Métodos de Análise de Solos. Instituto de Investigação Científica Tropical, Série Ciências Agrárias, vol. 10. Secretaria de Estado da Ciência e Tecnologia.

Quental, L., Bourguignon, A., Sousa, A.J., Batista, M.J., Brito, M.G., Tavares, T., Abreu, M.M., Vairinho, M., Cottard, F., 2002. MINEO Southern Europe environment test site. Contamination Impact Mapping and Modelling — Final Report. IST-1999-0337. http:// www.brgm.fr/mineo.

Srivastava, P.C., Gupta, U.C., 1996. Trace Elements in Crop Production. Science Publishers, Inc., USA.

Tavares, C.M.O.F., 1995. Contaminação por Hg do solo e plantas dos campos marginais do esteiro de Estarreja. Unpublished MSc Thesis. Universidade de Aveiro. 